\title{
Tectonic evolution of the Tombel graben basement, southwestern Cameroon
}

\author{
Department of Geology and Environmental Science, University of Buea, P.O. Box 63, South West Province, Cameroon. \\ Email:<mnjome@yahoo.com>and <chuhma@yahoo.com> \\ *Corresponding author
}

Planar structures (foliations and fractures) around the Tombel graben (southwestern end of the Central African Shear zone system) have been investigated and analyzed with the aim of unraveling the tectonic evolution of the basement. The foliations show two major trends, an older $N$-S-trending gneissose layering of uncertain age reworked by a later Pan-African (600 $\pm 50 \mathrm{Ma}) \mathrm{NE}-\mathrm{SW}$ ductile trend that is contemporaneous with sinistral shearing and mylonitization. The brittle phase characterized by NW-SE-trending open and partially filled fractures is younger than the mylonitization event and although it has not been dated, it is suggested that the origin of these fractures is linked to the onset of volcanism along the Cameroon volcanic line $~ 31$ m.y. ago. The mylonitic foliation is recognized for the first time and supports a tectonic evolution model for the Tombel graben in which ductile non-coaxial deformation was succeeded by brittle failure.

\section{Introduction}

This paper examines gneissose layering, mylonitic foliation and fractures (planar structures) in basement complex rocks of the Tombel graben (Southwest Cameroon), with the aim of unraveling the tectonic evolution of the basement. This region forms part of the Neoproterozoic fold belt (NFB) of Cameroon that can be traced into the northeastern Borborema Province of Brazil; a major part of the Neoproterozoic Braziliano belt (Tagne-Kamga, 2003). NFB is affected by the Central African Shear Zone (CASZ) of Braziliano/Pan-African age $(600 \pm 50 \mathrm{Ma})$, that is a pre-drift extension of the Pernambuco shear zone in NE Brazil (Archanjo et al. 2002; Ngako et al., 2003; Mvondo et al., 2003). This transcontinental shear zone is a major crustal discontinuity extending from northeastern Brazil into Cameroon (Figure 1) and is the focus of major international investigations (Caby et al., 1989; Van Schmus et al., 1995; Ferre et al., 1995). Deformation along the CASZ is not homogenous and is closely linked to granitic intrusion events. Separate regions of dextral and sinistral shearing as well as zones of reversal of shear sense have been described (e.g. Ngako et al., 2003). In all these studies, the segment of the CASZ around the Tombel graben has remained obscured because the graben is covered by Tertiary to Recent basaltic lava flows and over 80 pyroclastic cones $<1 \mathrm{Ma}$ old, that form part of the Cameroon Volcanic Line (CVL) (Regnoult, 1986; Neba, 1987). The occurrence of deformed basement rocks truncated by ductile and brittle features, some of which acted as pathways for magma ascent and eruption, makes the Tombel graben a suitable site for studying the evolution of the CASZ



Figure 1 Pre-drift (Pre-Mesozoic) reconstruction of Pan-African and Braziliano terranes (unshaded areas); BP-Borborema Province; shear zones (SF-Sanaga fault; CASZ-Central African Shear zone; P-Patos fault; PS-Pernambuco shear zone), cratonic belts (WAC-West African craton; CC-Congo craton; SFC-Sao Francisco craton) and the opening Atlantic ocean (A). Tertiary volcanoes of the Cameroon volcanic line (dark shades) and sediments (stippled areas) are shown (modified from Archanjo et al., 2002 and Ngako et al., 2003). Dark cross in square box is the approximate location of Tombel graben.

and its bearing on CVL volcanism. The relative timing of these events is still unclear in many parts of the CASZ. Recent mapping of parts of this graben (Njome, 2000; Njome et al., 2003) has revealed excellent exposures of the basement and has inspired this contribution. We show in this paper that an earlier N-S gneissose foliation of uncertain age was reworked by a ductile sinistral shear with a distinct Pan-African signature, resulting in a prominent NE-SW mylonitic foliation subparallel to the regional trend of the NFB and the Braziliano belt. This ductile event was succeeded by brittle failure resulting in more or less E-W to NW-SE-trending fractures. Some of these fractures are filled by basaltic dykes and veins providing evidence that the brittle event is linked to the uplift and onset of volcanism along the Cameroon volcanic line from $\sim 31 \mathrm{Ma}$ to Recent (Marzoli et al, 2000). No reversal of shear sense is documented and these results are significant for the wider international understanding of this transatlantic shear zone and its bearing on the evolution of western Gondwana.

\section{Geological overview}

The Tombel graben is one of a series of grabens that defines the alternation of horsts and grabens along the CVL. CVL is a linear array of numerous volcanic centres and anorogenic complexes 


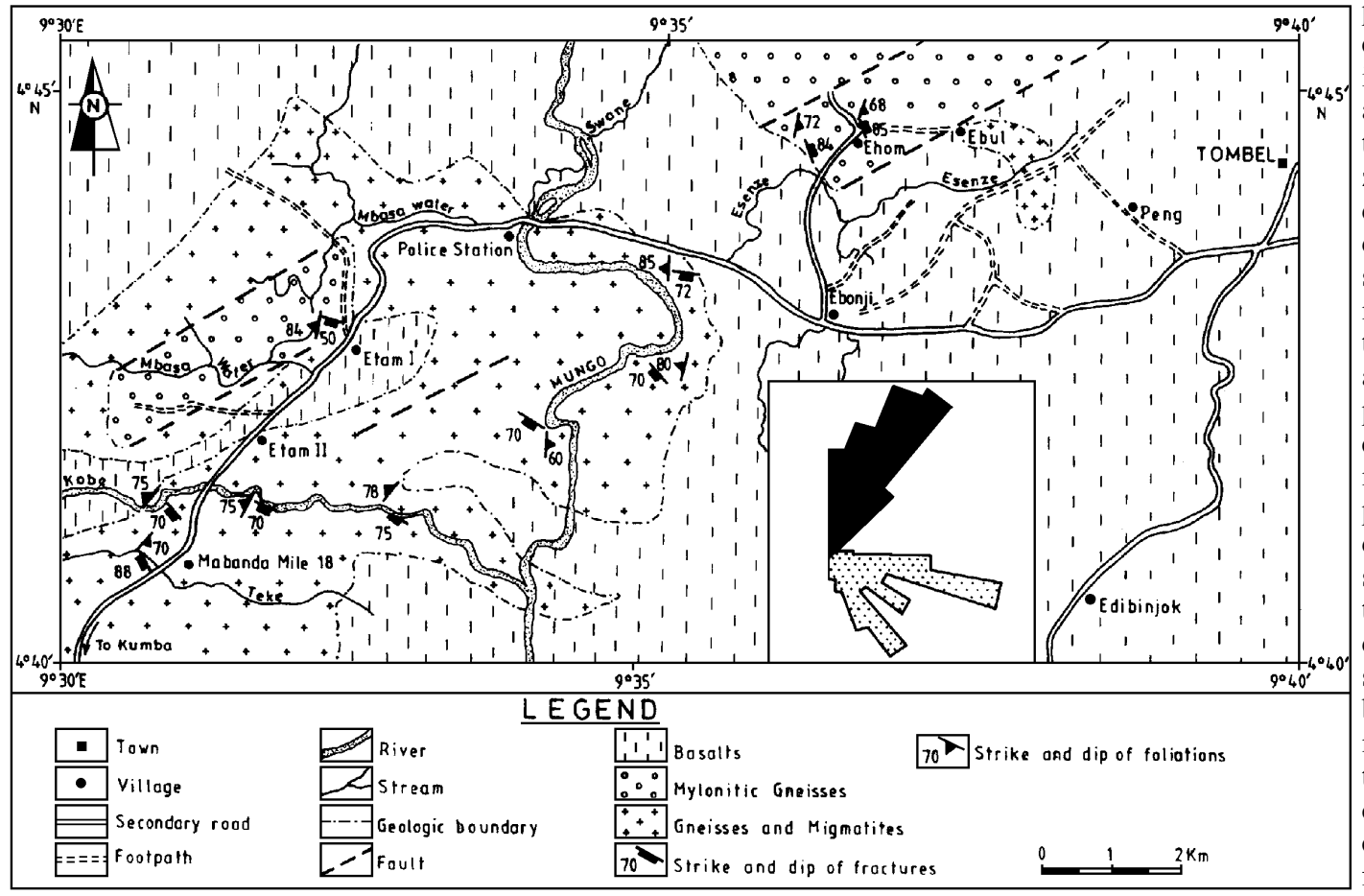

Figure 2 Structural and geologic map of the study area. Inset: rose diagram showing major structural trends: black-foliations; stippled-fractures (after Njome et al., 2003).

(Deruelle et al., 1987; Kamden et al. 2002; Suh et al., 2003; Montigny et al., 2004; Rankenburg et al., 2004). Several workers have postulated that the linear trend of volcanoes along the CVL is structurally controlled (Dumort, 1968; Tchoua, 1971; Regnoult, 1986; Nkouathio, 1997; Lamilen et al., 1998) by Braziliano/Pan-African $(600 \pm 50 \mathrm{Ma})$ structures that predate the onset of volcanism. The CVL volcanoes range in age from $<1$ to $\sim 31 \mathrm{Ma}$ and define a broad compositional range from basalts to rhyolites although intermediate magmas of tholeiitic character are absent. Mount Cameroon volcano is still active and last erupted in 2000 (Suh et al., 2003). Movements along the Pan-African structures have created basins such as the Lom basin (Ngako et al., 2003) and a series of shallow grabens such as the Tombel graben.

The Tombel graben as a whole consists of more than 80 volcanic cones and occasional basaltic lava flows. Few plutonic (syenites and gabbros; <70 Ma) complexes also outcrop in this graben. The metamorphic basement here comprises gneisses, biotite schist, migmatites and meta-granitoids, all of which have been locally mylonitized (Figure 2). Full descriptions of these basement lithologies are presented elsewhere (Njome et al., 2003) and only summarized here. Both the gneisses and the schists are low-grade metamorphic rocks evidenced by the appearance of biotite in the mode. The gneisses have distinct mineralogical layering consisting of alternating bands of quartz grains of variable sizes and biotite-dominated bands. Asymmetrical and symmetrical feldspar porphyroblasts in the gneisses define a strong mineral lineation subparallel to the alignment of mica flakes in the schist. The meta-granites are locally foliated and have the following deformation characteristics at the microscopic scale: wavy extinction in quartz, formation of myrrmekite at the expense of alkali feldspars, cleavage-related sliding in plagioclase feldspars and the development of secondary biotite. The mylonites derived from these precursor rocks show progressive increase in the intensity of deformation from the external limits of the shear planes to the centre. The mylonitized rocks have fractured and stretched quartz ribbons with an anatomosing pattern of intervening lenses of less deformed gneiss and schist. The quartz ribbons and a retrograde mineral assemblage comprising sericite, muscovite, chlorite and epidote define mineral lineation in the mylonites. Undeformed and asymmetrical protolith boudins, commonly elongated parallel to the mineral lineation, are good shear sense indicators and define an overall sinistral sense of shear. At the boundaries of the shear zone, the gneissose layering is deformed into small-scale drag folds that also show a sinistral sense of displacement. Some of these folds take the form of sheath folds and their apical direction is parallel to the stretching lineation. The sinistral sense of movement along the shear plane was also deduced from displacement of quartz veins, some of which show rotational movement. Within the ductile shear zone, the gneissose banding is rotated to become parallel to the mylonitic foliation. The fact that the ductile shear zone cuts across the gneissose layering and the presence of drag folds suggest that mylonitization succeeded the metamorphic layering. Other microscopic non-coaxial sinistral shear sense indicators observed include rotated quartz pressure shadows in a muscovite matrix, C-S fabrics, $\delta$ - structures and, $\sigma-$ structures (Njome et al. 2003).

\section{Mesostructural data and interpretation}

The main planar structures encountered are foliations and fractures A total of 123 measurements of dips and strikes of foliation and fracture surfaces were taken during the fieldwork; 58 for foliations and 65 for fractures. These raw data can be obtained from the authors upon request. The predominant foliation is a mylonitic foliation that is oblique, though locally parallel, to the gneissose banding and parallel to the regional CASZ strike-slip fault system. The foliation surfaces have high dips $\left(60^{\circ}\right.$ to $\left.90^{\circ}\right)$ predominantly to the west, while the fracture planes are all near vertical. These data, plotted on stereonets ( $\beta$-diagrams and $\pi$-diagrams) show that most of the foliations have a NE-SW trend while the fractures trend NW-SE (Figure 3). To get an overall orientation of the foliations and fractures, the poles of these planes have been plotted and contoured (Figure 4) using conventional techniques (Ragan, 1973). These density plots show the poles of the foliations concentrated in the NW and SE portions of the net (Figure 4a), confirming the dominantly NE-SW trend. Conversely, the NW-SE trend of the fractures is confirmed by the concentration of the poles in the NE and SW sectors (Figure 4b). In order to get the specific orientation of the foliations and the fractures, we constructed rose diagrams for each of the locations from which measurements were taken (Figure 5). These rose diagrams define two dominant directions for foliations - NE-SW (locations B, C, D, E, G, M and Q) and $\mathrm{N}-\mathrm{S}$ (locations $\mathrm{H}, \mathrm{I}$ and $\mathrm{J}$ ). Rose diagrams for fractures define more or less E-W and NW-SE trends. Figure 5 also shows form lines drawn on the basis of the raw structural data and rose diagram plots. With respect to the foliations, these lines show a sigmoidal structural form due to the superposition of the sinistral ductile shear zone on the erstwhile N-S-trending gneissose layering (Figure 5). The sinistral sense of movement deduced from the mesostructures and microstructures described above, most of which show rotational movement, confirm that deformation along the mylonitic trend was non-coaxial. The original gneissose layering had an N-S trend and 

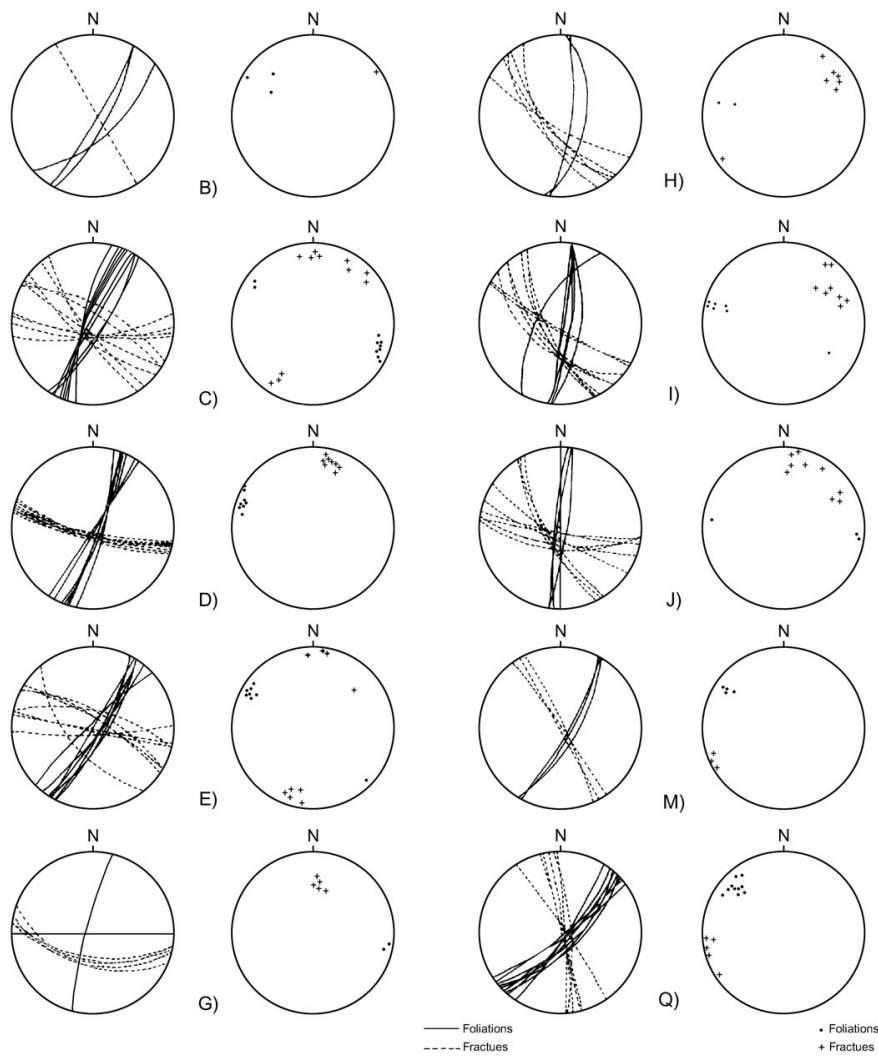

Figure 3 Wulff net lower hemisphere stereoplots ( $\beta$-diagrams) of foliation planes and fracture surfaces. Beside each plot is an equal-area lower hemisphere (Schmidt net) stereographic projection of poles ( $\pi$-diagrams) to the foliations and fractures. $B-Q$ refer to locations on Figure 5).

this was later distorted by the sinistral shearing during the mylonitization event. This effect is discernible in Figure 5 and on the rose diagram in Figure 6.

\section{Discussion}

The metamorphic basement in the Tombel graben region is marked by two major tectonic events:

1. A NE-SW (N20E-N50E) mylonitic foliation reminiscent of ductile deformation along a sinistral strike-slip fault. The mylonitization event reworked an older N-S (NOE-N20E) gneissose foliation. The age of the gneissose layering is uncertain. Although zircons from metamorphic rocks further north along the CASZ have been dated at $1100 \mathrm{Ma}$ (Toteu et al., 1994), similar work has not been done around the area of Tombel. Similarly, Pan-African ages have been obtained for mylonitized rocks in the northern part of the CASZ (Toteu et al., 1994) and in NE-SW-trending ductile fault zones in the Benue Trough in Nigeria, just west of the CVL (Maurin and Lancelot, 1990). The similarity between these dated mylonites and the ones we have described around the Tombel graben allow us to constrain the age of the mylonitization event as PanAfrican. The mylonites have a distinct greenschist facies assemblage with the appearance of sericite + chlorite + epidote, and the silicification of the matrix. The sericite in the mylonite forms from the breakdown of feldspars in the presursor

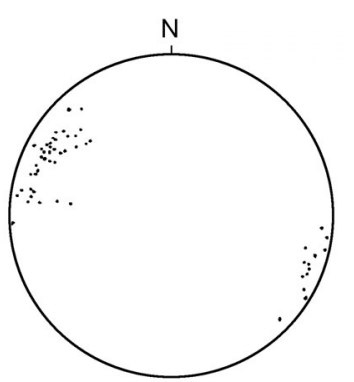

a)
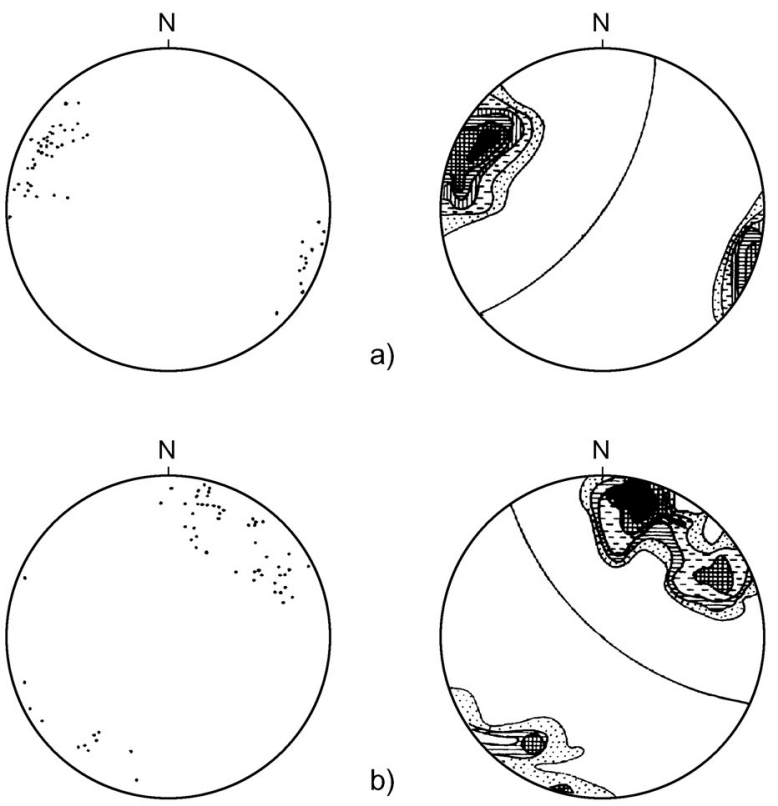

Figure 4 a) equal-area lower hemisphere stereographic projection of poles to foliations and density stereoplot (Schmidt lower hemisphere projection) for 55 points showing concentrations in the NW and SE portions (NE-SW trend). Contours 2-4-5-9-13\% per $1 \%$ area, maximum-16\%). b) equal-area lower hemisphere stereographic projection of poles to fracture surfaces and density stereoplot (Schmidt lower hemisphere projection) for 65 points showing concentrations in the NE/NNE and SW/SSW portions (NW-SE trend), Contours 2-3-5-8-10\% per 1\% area, maximum $14 \%$.

rocks and points to the fact that mylonitization was accompanied by fluid infiltration resulting in retrograde metamorphism.

2. A younger brittle event marked by three principal sets of fractures: N140E-N150E, N120E-N130E and N90E-N110E. Field relationships indicate that these fractures truncate the ductile foliation. On a regional scale, similar brittle features postdating a ductile shearing regime have been well documented in the adjacent Cretaceous Benue Trough sedimentary basin in Nigeria (Maurin and Lancelot, 1990). These fractures often have volcanic (basaltic) veins and these have been dated at $147 \pm 7 \mathrm{Ma}$ in the Benue Trough (Maluski et al., 1995) and believed to mark the early stages of the opening of this basin. Volcanism along CVL only commenced $\sim 31$

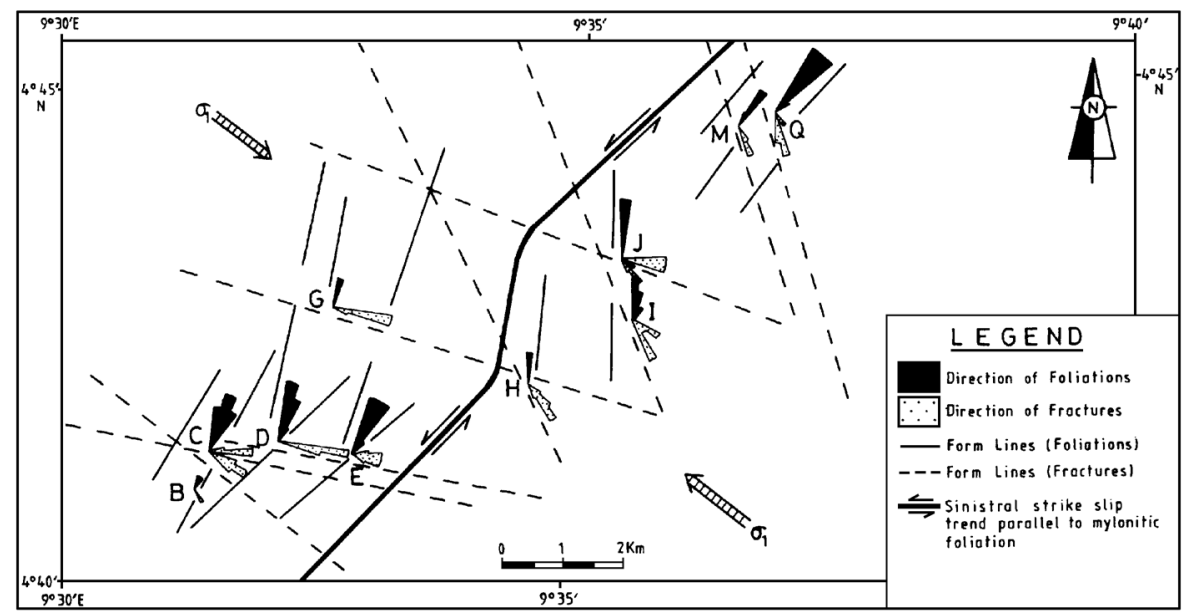

Figure 5 Rose diagrams (for geologic map shown on Figure 2) showing main concentrations for foliations and fractures in each location of the study area $(B, C, D, E$, $G, H, I, J, M$ and $Q)$, and form lines drawn on the basis of these rose diagrams. $\left(\sigma_{I}\right.$ is deduced from conjugate fractures). 


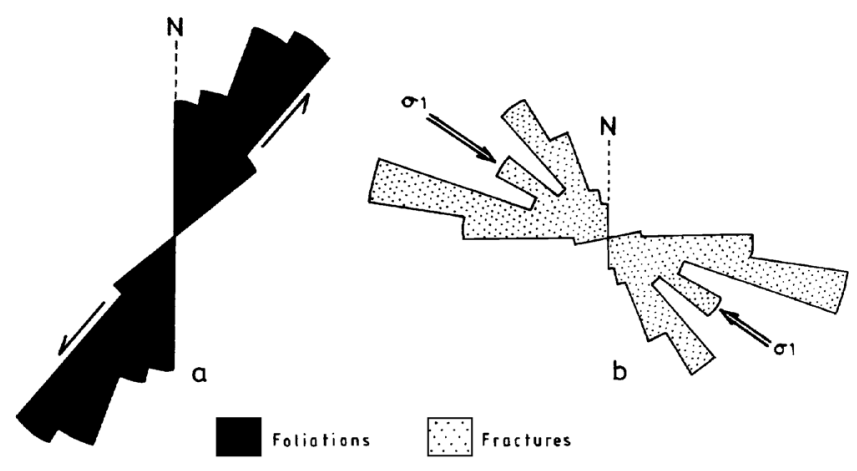

Figure 6 Cumulative rose diagram of foliation planes (a)depicting two main structural trends (N20E-N50E and NOE$N 20 E)$ of fracture surfaces, $(b)$-depicting three main structural trends (N90E-N110E, N140E-N150E and N120E-N130E).

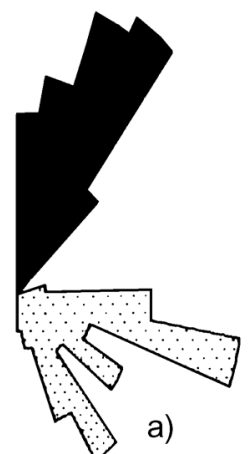

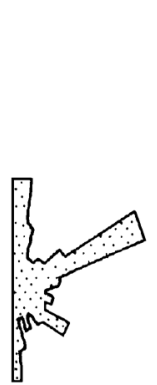

b)

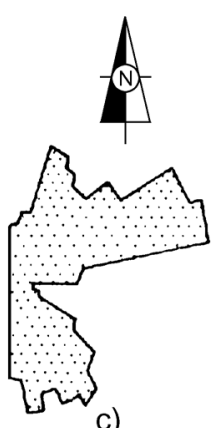

c)
Figure 7 Cumulative rose diagram for lineaments of the western part of Tombel graben of South Western Cameroon (a-this study), eastern part of Tombel graben (b-after Nkouathio, 1997) and for the entire country (c-after Deruelle and Regnoult, 1983). Same symbols as Figure 6.

Ma ago (Marzoli et al. 2000) and this brittle event is judged to be related to the early stages of uplift and volcanism. Although these structures are older in the Benue trough, there is ample evidence that in this basin the brittle fractures and faults have remained active up to $\sim 14 \mathrm{Ma}$ (Maurin and Lancelot, 1990). Therefore the tectonic evolution of the CVL and the Benue Trough in the Cretaceous appears to be dominated by this fracturing episode. The case has often been made that the Benue Trough and the CVL have a similar origin with the CVL representing an eastward migration of rifting away from the Benue Trough (Fairhead and Okereke, 1987). The sequence of events (ductile deformation followed by brittle failure) around the basement of the Tombel area matches that within the Benue Trough.

The tectonic evolution in the Tombel graben segment of the CASZ system commenced with ductile deformation and terminated with brittle deformation. This is a classical feature of brittle-ductile shear zones (Suh and Dada, 1997; Imber et al., 2001), although shear zones in which macroscopically brittle deformation predates a ductile event have also been described (see Imber et al., 2001 and references therein)

Figure 7 is a cumulative rose diagram showing foliation and fracture directions obtained in this study compared with that of Nkouathio (1997) for the eastern part of the Tombel graben and that presented in Deruelle and Regnoult (1983) for the whole of Cameroon. Nkouathio (1997) presented three groups of planar structures, the most important being that oriented NE-SW (Figure 7b), i.e. N60E-N70E. This is slightly different from the NE-SW principal mylonitic foliation in this study with average value of N30E-N40E. Despite this discrepancy, the important NE-SW direction is clearly discernible from both studies. This is a significant contribution to the tectonics of this region. Another major difference is that Nkouathio (1997) did not emphasize the mylonitic foliation that we have docu- mented here. Thus, while the structures in this study are divided into foliations and fractures, Deruelle and Regnoult (1983) and Nkouathio (1997) presented all their data as fractures, overlooking the mylonitic foliation and the role of ductile sinistral shearing in the tectonic evolution of this region. However, similar to the results obtained from this study, Lamilen et al. (1998) reported a N18E$\mathrm{N} 25 \mathrm{E}$ mylonitic foliation direction along the CVL within gneisses and granitic-orthogneisses. In their study, Lamilen et al. (1998) stated that this N18E-N25E foliation is associated with isoclinal folds that we did not observe in this region. This indicates how heterogeneous deformation along the CASZ is, and underscores the need to keep investigating it by looking at individual segments at a time.

\section{Conclusion}

In this study, we have produced a structural and geological map of the western part of the Tombel graben (Figure 2). We have also deduced for the first time, a major sinistral shear zone in the region, mainly from the orientation of mylonitic bands. We also conclude that the fractures (brittle deformation) are younger than the foliations and the region experienced a ductile to brittle transition and noncoaxial deformation. These results contribute to the better understanding of this region in relation to the deformation, volcanism and the origin and evolution of the CVL and the Benue Trough; two related geological megastructures that dominate the West African sub-region.

\section{Acknowledgements}

The data presented here form part of MSN's M.Sc. thesis supervised by CES. The authors acknowledge support from colleagues at University of Buea. Comments by Dr H. Stel on earlier versions of the manuscript were very constructive and we are indebted to him for all his help.

\section{References}

Archanjo, C.J., Trindale, R.I.F., Bouchez, J.L., and Ernesto, M., 2002, Granite fabric and regional-scale strain partitioning in the Serido Belt (Borborema Province, NE Brazil), Tectonics, v. 21, no. 1, pp. 1-14.

Caby, R., 1989, Precambrian terranes of Benin-Nigeria and northeast Brazil and the late Proterozoic South Atlantic fit: Special paper, Geological Society of America, v. 230, pp. 145-158.

Deruelle, B., and Regnoult, J.M., 1983, Carte tele-interpretative des lineaments de la Republique Unie du Cameroun au nord du $4^{\mathrm{e}}$ parallele (1/ 1,000,000): Min. Mines et Energie, Direction des Mines, Yaounde, Cameroon.

Deruelle, B., N'ni, J., and Kambou, R., 1987, Mount Cameroon: an active volcano of the Cameroon Line. Journal of African Earth Sciences, v. 6 , no. 2 , pp. $197-214$

Dumort, J.C., 1968, Notice explicatif sur la feuille Douala-Ouest, Carte geologique de reconnaissance a l'echelle du 1/500,000, Min. Mines et Energie, Direction des Mines et de la Geologie du Cameroun, pp. 68.

Fairhead, J.D., and Okereke, C.S., 1987, A regional gravity study of the West African rift system in Nigeria and Cameroon and its tectonic interpretation, Tectonophysics, v.143, pp. 141-159.

Ferre, E., Gleizes, G., and Bouchez, J.L., 1995, Internal fabric and strike-slip emplacement of the Pan-African granite of Solli Hills, northeast Nigeria, Tectonics, v. 14, pp. 1205-1219.

Imber, J., Holdsworth, R.E., Butler, C.A. and Strrachan, R.A., 2001, A reappraisal of the Sibson-Scholz fault zone model: the nature of frictional to viscous ('brittle-ductile') transition along a long-lived crustal scale fault, Outer Hebrides Scotland, Tectonics, v. 20, no. 5, pp. 601-624.

Kamdem, J.B., Kraml, M., Keller, J., and Henjes-Kunst, F., Cameroon Line magmatism: conventional $\mathrm{K} / \mathrm{Ar}$ and single-crystal laser ${ }^{40} \mathrm{Ar} /{ }^{39} \mathrm{Ar}$ ages of rocks and minerals from the Hossere Nigo anorogenic complex, Cameroon, Journal of African Earth Sciences (in press) . 
Lamilen, B.D., Moundi, A., Moupou, M., and Minyem, D., 1998, Control structurel du socle dans la morphologie du massif anorogenique du Koupe (Ligne du Cameroun), Geoscience au Cameroun, v. 1, pp. 191196.

Maluski, H., Coulon, C., Popoff, M. and Baudin, P., 1995, ${ }^{40} \mathrm{Ar} /{ }^{39} \mathrm{Ar}$ chronology, petrology and geodynamic setting of Mesozoic to Early Cenozoic magmatism from the Benue Trough, Nigeria, Journal of the Geological Society of London, v. 152, 311-326.

Maurin, J.C., and Lancelot, J.R., 1990, Structural setting and U-Pb dating of uranium mineralizations from the northeastern part of Nigeria (Upper Benue Region), Journal of African Earth Sciences, v. 10, no. 3, pp. 421433.

Marzoli, A., Piccirillo, E.E., Renne, P.R., Bellieni, G., Lacumin, M, Nyobe, J.B. and Tongwa, A.T., 2000, The Cameroon volcanic line revisited: petrogenesis of continental basaltic magmas from lithoshperic and asthenospheric sources, Journal of Petrology, v. 41, 87-109.

Montigny, R., Ngounouno, I. and Deruelle, B., 2004, Ages K-Ar des roches magmatiques du fosse de Garoua (Cameroun): leur place dans le cadre de la ìligne du Camerounî, Comptes Rendu Geoscience, v. 336, 1463-1471.

Mvondo, H., den Brok, S.W.J., and Mvondo Ondoa, J., 2003, Evidence for symmetrical extension and exhumation of the Yaounde nappe (PanAfrican fold belt, Cameroon), Journal of African Earth Sciences, v. 36, pp. 215-231.

Neba, A.S., 1987, Modern geography of the Republic of Cameroon, 2nd edition: Neba Publishers, Camden, New Jersey, pp. 204.

Ngako, V., Affaton, P., Nnange, J.M., and Njanko, T.H., 2003, Pan-African tectonic evolution in Central and Southern Cameroon: transpression and transtension during sinistral shear movements, Journal of African Earth Sciences, v. 36, pp. 207-214.

Njome, M.S., 2000, Structural features of the migmatite-gneiss/mylonite association of the Tombel graben, south western Cameroon, M.Sc. thesis; Geology Department, University of Buea, Cameroon (unpublished), pp. 96.

Njome, M.S., Suh, C.E., and Ghogomu, R.T., 2003, A microstructural approach to interpreting the structural setting of the Tombel graben, south western Cameroon, GeoActa, v. 2, pp. 181-200.

Nkouathio, D.G., 1997, Le volcanisme recent du graben de Tombel (province du littoral et du sud-ouest, Cameroun): volcanologie, geochimie, petrologie et valeur agricole, These Doctorat 3eme cycle, Universite de Yaounde I, Cameroun (unpublished), pp. 78.

Ragan, D.M., 1973, Structural geology: an introduction to geometrical techniques, 2nd edition: John Wiley and Sons, New York, pp. 208.

Rankenburg, K., Lassiter, J.C., and Brey, G., 2004, Origin of megacrysts in volcanic rocks of the Cameroon volcanic chain $\tilde{n}$ constraints on magma genesis and crustal contamination, Contributions to Mineralogy and Petrology, v. 147, pp. 129-144

Regnoult, J.M., 1986, Synthese geologique du Cameroun: Imprimerie National, Yaounde, pp. 119.

Suh, C.E., and Dada, S.S., 1997, Fault rocks and differential reactivity of minerals in the Kanawa Violaine uraniferous vein, NE Nigeria, Journal of Structural Geology, v. 19, no. 8, pp. 1037-1044.

Suh, C.E., Sparks, R.S.J., Fitton, J.G., Ayonghe, S.N., Annen, C., Nana, R., and Luckman, A., 2003, The 1999 and 2000 eruptions of Mount Cameroon: eruption behaviour and petrochemistry of lava, Bulletin of Volcanology, v. 65, pp. 267-281.
Tagne-Kamga, G., 2003, Petrogenesis of the Neoproterozoic Ngondo plutonic complex (Cameroon, West Central Africa): a case of late-collisional ferro-potassic magmatism, Journal of African Earth Sciences, v. 36, pp. 149-171.

Tchoua S.F., 1971, Le volcanisme strombolien de la plaine de Tombel (Cameroun), Annals of the Faculty of Science, University of Yaounde, v. 7/8, pp. 53-78

Toteu, S.F., Van Schmus, W.R., Penaye, J., and Nyobe, J.B., 1994, U-Pb and Sm-Nd evidence for Eburnian and Pan-African high grade metamorphism in cratonic rocks of southern Cameroon, Precambrian Research, v. 67, pp. 321-347.

Van Schmus, W.R., Brito Neves, B.B., Hackspacher, P.C., and Babinski, M., $1995, \mathrm{U} / \mathrm{Pb}$ and $\mathrm{Sm} / \mathrm{Nd}$ geochronologic studies of the eastern Borborema Province, north eastern Brazil: initial conclusions, Journal of South American Earth Sciences, v. 8, pp. 247-266.

Manga Stephen Njome, received his B.Sc in Geology from the University of Buea in 1996 and M.Sc. in Applied Structural Geology from the same University in 2001. He is an Instructor of Geology and a PhD student in the Department of Geology and Environmental Science of the University of Buea. His research interests are on applied structural Geology, microtectonics as well as volcanology. His current project focuses on the study of volcanic products in understanding the evolution and behaviour of volcanoes.

Emmanuel Cheo Suh, PhD, is a Senior Lecturer in the Department of Geology and Environmental Science, University of Buea. His main research interests are applied structural geology, structural controls of shear zone-hosted mineral deposits and petrochemistry of volcanic rocks.

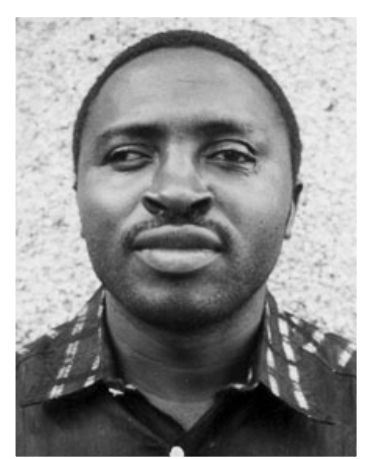

